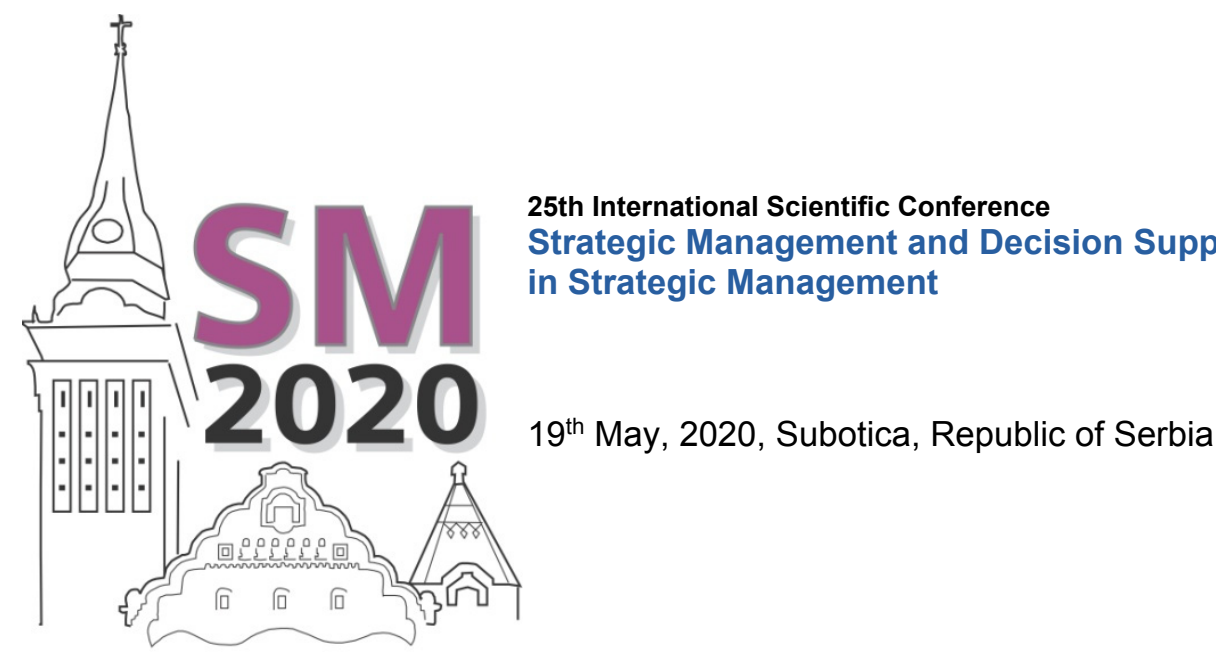

Valentina Vukmirović

Institute of economic sciences,

Belgrade, Serbia

valentina.vukmirovic@ien.bg.ac.rs
Ivana Domazet

Institute of economic sciences,

Belgrade, Serbia

ivana.domazet@ien.bg.ac.rs
Milica Kostić-Stanković

Faculty of organizational sciences,

Belgrade, Serbia

kostic.milica@fon.bg.ac.rs

\title{
PERSONALIZED SOCIAL MEDIA COMMUNICATION BASED ON MILLENNIALS' ATTITUDES
}

\begin{abstract}
As a result of intense and ever-growing technological development, as well as the increase of digital media usage in everyday life, communication strategies have undergone profound transformations in order to adapt to specific conditions of online environment. Due to the interactive essence of Internet communication, which is being realized on social media and other online platforms, the need for engaging social media users in creating communication strategies has emerged. Furthermore, demographic trends have resulted in the shift of target audience structure, since generation Y members (i.e. millennials) have growing importance within the structure of contemporary society. This generational cohort, among its other characteristics, can be depicted by its distinct sophistication in terms of communication preferences. To be more precise, this generation expects to be provided with interactive, real-time and personalized communication, which is adjusted to social media platforms they use and can be consumed on the go. Therefore, the aim of this paper is to observe and accentuate the changes in media communication strategies caused by millennials and their extensive use of technology. The results obtained from the research conducted in this paper can be useful for both communication researchers and practitioners, and can be used as guidelines for creating digital communication strategies for millennials.
\end{abstract}

Keywords: generation Y (millennials), social media, personalized marketing communication, long-term customer relationship.

\section{INTRODUCTION}

Marketing communication environment has changed enormously during the last few decades, as technology and internet have fundamentally changed the manner in which the "world interacts and communicates" (Keller, 2009). Lamberton and Stephen (2016) argue that marketing communication has evolved and gone through significant changes since 2000, stating that digital media platforms have provided new manners for "reaching, informing, engaging and learning about customers" as well as selling products and providing services for them. Authors emphasize the influence of technological innovations, such as wide availability of home and wireless internet connection, occurrence and widespread usage of social media and adoption of smartphones and other portable devices on changes in contemporary marketing communication. Killian and McManus (2015) state that digital era has influenced customers' expectations of marketing communication. Namely, digital technology and rise of social media have resulted in revolutionary changes in the communication field, since they provoked a shift from mass media communication to interactive and personalized social media communication.

Authors report that social media have, to a large extent, become a substitute for traditional media (Bruhn, Schoenmueller, \& Schäfer, 2012). The interactive nature of new media has resulted in twofold benefits. Firstly, it has allowed its users to

How to cite: Vukmirović, V., Domazet, I., Kostić-Stanković, M. (2020). Personalized Social Media Communication Based on Millennials' Attitudes. In Proceedings of the 25th International Scientific Conference Strategic Management and Decision Support Systems in Strategic Management. https://doi.org/10.46541/978-86-7233386-2_13 
share and exchange information with large audiences, create virtual groups and communities in order to support different opinions, causes and incentives (Gummerus, Liljander, Weman, \& Pihlström, 2012). Moreover, it provided the opportunity for organizations to establish direct communication with their target audiences and strenghten the mutual bond (Killian \& McManus, 2015). Authors argue on different manners in which this connection can be enhanced, emphasizing message personalization as a strategy for reaching and improving communication with contemporary media customers (Wind \& Rangaswamy, 2001). (Smith, 2011) states that "online recommendations" can be observed as an effective approach towards establishing personalized communication.

According to Oxford dictionaries definition, generation Y members are individuals born between 1980s and 1990s, mostly children of baby boomers, and are typically perceived as digitally literate and familiar with electronic technology (oxforddictionaries.com). Generation Y members are also known as millennials, as they were growing up at the beginning of new millennium. Due to the fact that they have grown up during intensive development of digital and Internet technology, this generational cohort is also known by the names such as the Digital Natives or the Net Generation (Kilian, Hennigs, \& Langner, 2012) emphasizing their propensity towards integrating digital technologies in all aspects of their lives (Towers, 2017). Observing media consumption among generation Y members, authors have reported that more than $90 \%$ of research participants claimed using some type of social media on a daily basis, most often for collecting and disseminating information (Tkalac Verčič \& Verčič, 2013). It is has also been reported that young adults perceive social media as valuable news source (Wohn \& Bowe, 2016), while others use it to obtain information in decision-making processes (Wang, Yu, \& Wei, 2012). Therefore, it can be concluded that, alongside rapid technological development, contemporary communication is shaped and formed according to social media usage trends generated by $\mathrm{Y}$ generation members.

Considering above mentioned specificities of generation Y members, regarding their communication preferences and extensive usage of technology, this paper provides information on how contemporary communication is altered due to lifestyle changes and manners in which information are collected and disseminated by members of observed target audience. Furthermore, this paper provides an insight into the role of contemporary media users in creation of contemporary communication flows. Based on the results of a desk review, authors of this paper draw a conclusion that, on a global level, generation Y members have growing significance in shaping media communication. To examine this assumption within generation Y members in Serbia, authors conducted a research among university student population. Research results and findings are presented in the discussion section of this paper, while limitations and future research recommendations are presented in the conclusion.

\section{LITERATURE REVIEW}

Researchers have reported significant influence of social media and multimedia platforms on modern communication flows, as their role in disseminating information has been noted by numerous authors (Ibrahim, Wang, \& Bourne, 2017) (H. U. Khan et al., 2017) (M. L. Khan, 2017). Authors argue how social media platforms have allowed its users to state their opinion freely, expressing approval or discontentment by writing comments and reviews or giving ratings in order to share their positive or negative experiences, attitudes or beliefs. Therefore, it can be concluded that basic advantages of social media, as "web sites and online tools" (Ibrahim et al., 2017), is the fact that they allow its users to create and exchange content and provide the opportunity for individuals, groups and organizations to establish mutual interaction (Wagner, Jiang, 2012).

Researchers have distinguished the advent of generating and sharing information among users as co-creation, stating that it involves two or more sides willing to create value by obtaining new knowledge and sharing it with others through interactive processes (Prahalad, Ramaswamy, 2004). Furthermore, authors claim that users enjoy observing other users' personal data and social media profiles, rather than "mass produced content" created by corporations (McCorkindale et al., 2013) as it can be noticed that customers are more confident about other customers judgment than the content created by companies (Taken Smith, 2011). Within social media, value can be created in different forms and with different aims, as the number of these applications is constantly growing. Furthermore, social media sites tend to significantly vary from one another, as they are created for different target audiences. For example, LinkedIn has become most prominent social media site for career development, as $50 \%$ of college graduates in the USA actively use this network (Smith, Anderson, 2018). On the other hand, YouTube is observed as a social media platform which principally provides entertaining content, while its educational aspect can not be neglected as well (Khan, 2017). Positive correlation has been established between advertising on Facebook and purchase decision making among millennials (Duffett, 2014), while emotional aspect of Twitter messages created by organizations can provoke user engagement behavior and consequently development of "strong online communities" (Ibrahim et al., 2017). As researchers claim that generation Y members are active creators of social media content who prefer using online platforms which allow them to make contibution (Bolton et al., 2013), the following part of this paper will consider the nature and motivations of this generational cohort for engaging in interactive media platforms. 


\subsection{Trends in contemporary marketing communication}

One of the basic characteristics of communication that takes place on social networks is the fact that created content is no longer under the control of companies and marketing experts, which enables social media users to freely express their opinion, attitudes, discontentment or positive impressions regarding different issues. It is claimed that popularity of social media among their users is based on the fact that they want to connect with other users with whom they share similar interests. Extensive use of interactive media has provided the opportunity for electronic word-of-mouth (eWOM) communication development (Cheung, Lee, \& Rabjohn, 2008). This phenomenon has influenced the process of data gathering, knowledge acquiring and the shift of focus from traditional media to digital media as the new authority in collecting pieces of information. Authors argue that users of new media proactively search for information on products and services and seek advices from their online contacts, as they trust consumer generated content more than information provided by traditional media (Cheung \& Thadani, 2012). This propensity of contemporary media users has resulted with the occurence of zero and third moment of truth, activities initiated by the need to learn more about the product or service or state the experience related to it (Moran et al., 2014). In that manner, social media users were promoted to communication creators rather than passive recipients of messages. This claim can be supported by opinion of Katz et al. (1974) who stated that "media effects are brought about by users rather than the media itself".

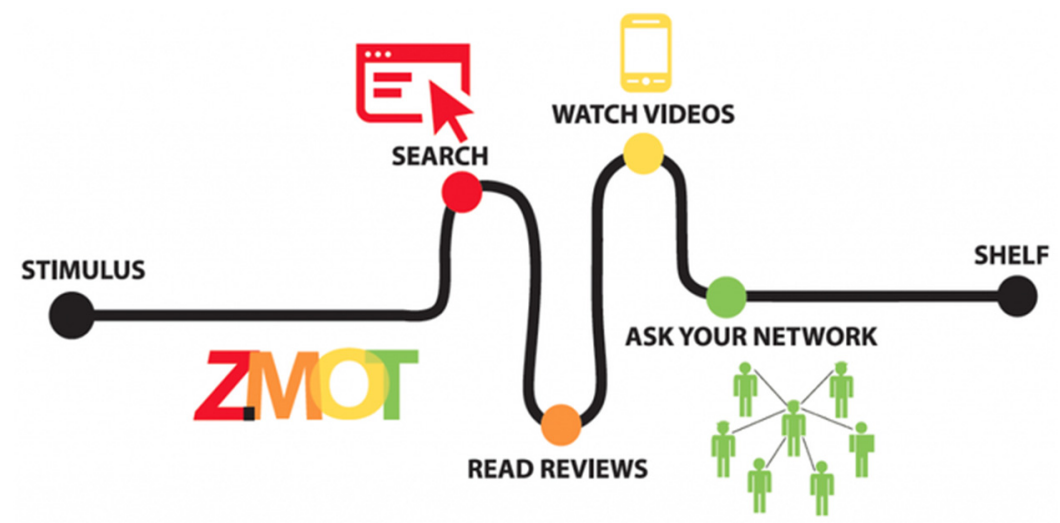

Figure 1. "The Zero Moment of Truth" - Google Source: napiermkt.com

Chen and Xie (2004) observe customer online reviews as a new element of marketing communication mix that has a growing importance in contemporary communication. Other authors observe social media as a "hybrid element of promotion mix" due to the fact that they provide companies with the opportunity to conduct direct and interactive communication with customers, while allowing customers to establish mutual communication and share information with each other (Mangold, Faulds, 2009). Furthermore, organizations have realized that conducting advertising activities on social media is far more cost effective as it allows expanded message reach, which is disseminated as a consequence of user activities rather than buying expensive traditional media space.

Due to this shift, organizations have become avare of the need to include their target audiences in communication processes, not just because their opinion matters, but because eWOM activities provide more attention and media space for their products, services, or iniciatives they promote. Therefore, some authors propose that classical hierachy of effects models of marketing communication should be altered, so that they include the aspect of product evaluation and advocacy (Hudson, Hudson, 2013). Authors emphasize the role of social media in these stages, since social groups are observed as relevant sources of information. Furthermore, Clark (2013) states that generation Y use social media as a complaint channel as well, since they feel confident enough to express discontentment on personal or organizations' profiles. Author argues on the fact that accumulation of negative word-of-mouth communication can jeopardize the image of an organization, especially beacuse organizations no longer have control over content generated in online environment. Investigating the impact that members of generation $\mathrm{Y}$ have had on information flow within social media, researchers noticed the need to observe their role in shaping business communication as well (Helal et al., 2018). Authors emphasize specificities of this generational cohort in terms of communication perception. Namely, it can be concluded that young adults worldwide expect real time communication and instant responses followed by multimedia content which can provide even more detailed display of products or services they are interested in.

Authors argue that since social media users are increasingly leaning on these platforms for communication and information exchange, continuous rise of their importance and authority among generation $\mathrm{Y}$ is to be expected in the future. The fact that generation Y members are the most prominent users of social media (Kennedy, 2017) resulted in marketing practicioners' interest to motivate these users to generate favorable content for their products or services online. Therefore, various strategies have been developed with the aim of taking advantage of user content creation activities. It can be noticed that organizations encourage creation of user generated content through developing platforms which allow target audience members to write reviews, comments, give ratings and get in touch with organizations through their profiles on social media. By sharing their oppinion through virtual suggestion boxes and online communities, web-based 
idea markets and online surveys, social media users have surpassed the communication barrier between themselves and organizations.

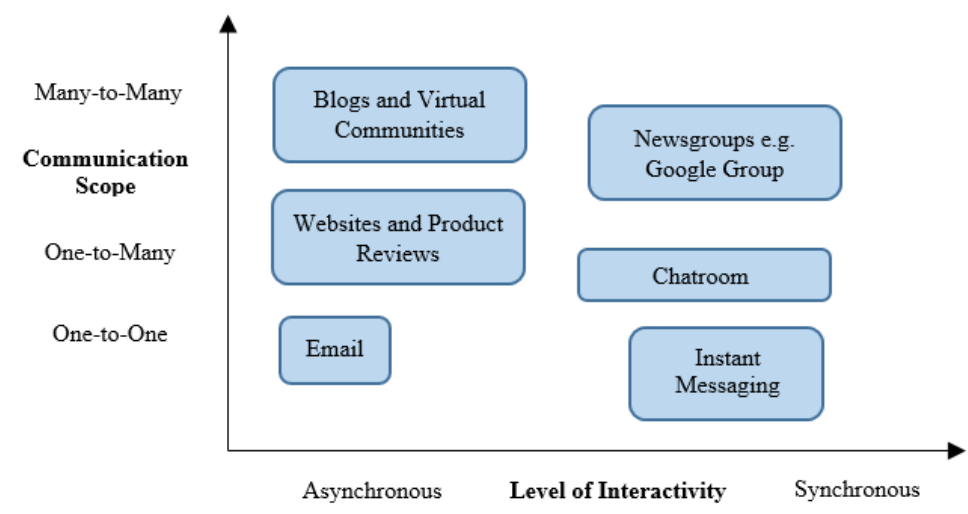

Figure 2. A Typology of Electronic Word of Mouth (eWOM)

Source: Litvin et al. (2008)

Apart from opinion stating, it is argued on other motives for participating in electronic word-of-mouth communication (Campbell, 2017). Namely, author states that social media users seek for peer approval and assistance when making decisions, since eWOM communication provides information which is percieved as more honest, unbiased and created by people of similar interests, attitudes and preferences. The propensity towards sharing personal beliefs and judgments in digital environment has resulted in the occurence of blogging phenomenon. It has resulted in promotion of influential individuals into leaders of public opinion, and resulted in the fact that even traditional media base their reports and stories on blog content (Khan et al., 2017). Therefore, communication experts argue on the necessity of engaging public opinion leaders into creation and realization of communication strategies since their content is percieved as more genuine and realistic than traditional advertising which provides only beneficial perspectives and outcomes, often significantly enhanced. Since literature indicates that genuine, transparent and authentic communication is what contemporary society expects on individual and organizational level, authors of this paper made an assumption that generation $\mathrm{Y}$ is the most competent for providing and maintaining content which matches these demands. This hypothesis is examined in the following section of this paper by applying desk research methodology.

\section{MILLENNIALS' ROLE IN SHAPING CONTEMPORARY MARKETING COMMUNICATION}

Members of generation Y most prominent characteristic is their propensity towards technological devices usage and constant communication which is being performed throughout social media platforms. It is estimated that $88 \%$ of generation Y members, or 1.5 billion people worldwide use social media (quickmarketing.com).

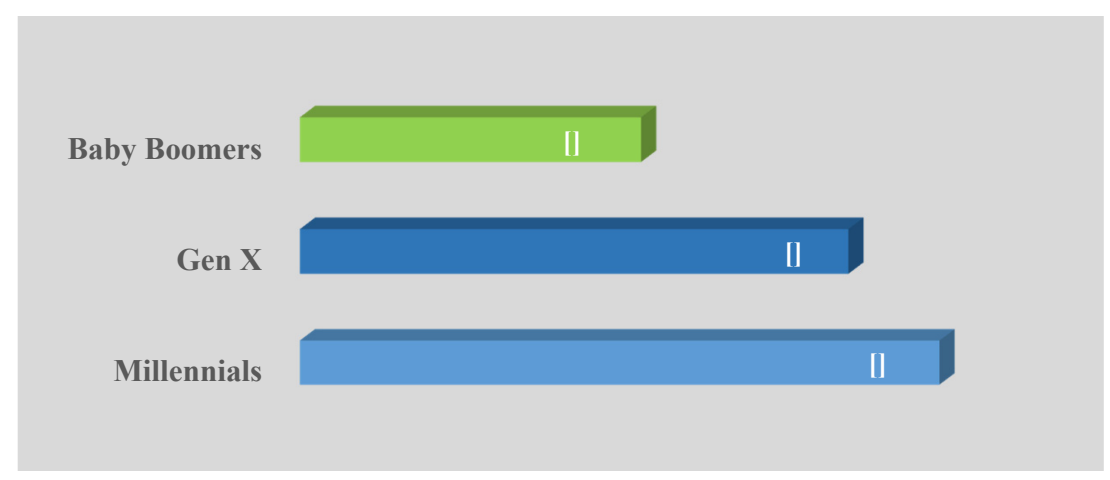

Figure 3. US Social media users by generation Source: Emarketer (2019)

According to Business Insider research (2018), among generation Y in USA, mostly used social media network is Facebook, which counted almost 60 million users in 2018, with the number of users constantly growing (businessinsider.com). The second most used social media among millennials in USA is Instagram. Furthermore, Google reports stated that $70 \%$ of generation Y members used multimedia platform YouTube to gain new knowledge about something they are interested in or learn how to do something, while $45 \%$ social media users within the same generational cohort stated that this platform inspired them to make life changes. Furthermore, it is stated that when learning something new millennials are almost three times more likely to acquire new information by watching a YouTube video than search 
for them in books. Moreover, $47 \%$ of research participants claimed that they watch videos on YouTube in order to improve their health status (thinkwithgoogle.com).

Due to extensive use of social media, significant number of this generational cohort uses social media to stay in touch with current events and obtain news and information. American Press institute research indicated that $88 \%$ of generation Y members uses Facebook to get news, while 33\% of this generational cohort members use Twitter to keep themselves informed (americanpressinstitute.org). Researchers have also reported that more than $40 \%$ of social media users who are 19 to 29 years old use social media platforms while searching for new employment, whereas $80 \%$ of employers use professional social media network LinkedIn in order to find suitable candidates to hire in their organizations (statista.com). Generation Y members are also prone to use social media and start their own blogs in order to create a prolific career. According to the result of Rice University research, one of generation Y distinguishing characteristics is the idea of starting business ventures on their own, having more than one stream of income and therefore becoming freelancers in several niches concurrently (forbes.com). Same research indicated that among this generation, blogs are being used for education and knowledge dissemination as more than $60 \%$ of its users in USA possess or are in the process of obtaining a college degree. Nonetheless, entertainment and seeking for inspiration provoke the interest to use these platforms as well.

Due to intense spread of social media sites application in different spheres of life, these platforms are being used not just for informal peer communication, but also for marketing purposes as many organizations and individuals use them to promote and advertise their ideas, products, services or incentives they support. Furthermore, marketing practitioners tend to create advertising content which is entertaining, engaging and personalized. What's more, it is reported that generation Y members freely express their wish to be engaged in organizations' communication activities. This can be proved by a statement made by Pempek et al. (2009) who claim that college students prefer to be "stars of their own production" and rather watch social media content created by their friends and connections on social media, than content created by organizations for large audiences. Therefore, authors investigate how marketing communication can benefit from "informational practices" of generation Y members, stating that "eWOM revolution" has emerged as a result of rising popularity of review and recommendation sites such as TripAdvisor and Yelp or Airbnb which provides accommodation booking services as well as sharing experiences and providing advices. Popularity of these sites can be explained by the fact that generation Y finds content created on social media more valuable and genuine, as it has already been revised by people with similar tastes, opinions and attitudes (Hardey, 2011). Research conducted by Moore (2012) indicated that millennials apply interactive technologies with the aim of collecting information "on the go" while at the same time entertaining themselves, preferably by using mobile devices. According to Hall (2018) eight out of ten millennials do not make purchase decision without consulting reviews, while $45 \%$ of research participants stated that they prefer online shopping because it allows them to collect additional information on product characteristics and prices (independent.co.uk). According to above mentioned statements, it can be concluded that contemporary media communication created for the needs of generation Y members should be interactive, personalized and adapted to the latest technological devices.

\section{CONCLUSION}

Due to growing significance and usage of interactive technologies in daily communication, researchers have noted the significance of observing how new media, gadgets and prominence of new generational cohorts shapes contemporary communication flows. Social media and interactive platforms have greatly altered the way in which modern society communicates. This has provoked intense changes in business communication as well. Social media has enabled customers to connect with each other and form loyalty networks for brands, as well as discussion groups to exchange opinions, impressions, create recommendations or express dissatisfaction with products or services. Organizations have recognized the impact that social media communication can have on the image and reputation of the brand, as well as for enhancing relationship with customers. The potential of interactive platforms is reflected in the ability to build a direct relationship with customers, gain more comprehensive insight into their preferences and, based on the information generated, communicate with them according to their needs and expectations.

Considering the fact that drivers of these changes are generation $\mathrm{Y}$ members, the first digitally literate generation, the focus of this paper was directed towards considering the attitudes, needs and preferences of this generation regarding communication initiated by brands and organizations on social networks. Through a thorough review of contemporary and relevant literature, the authors of this paper identified key features of contemporary communication on social networks based on generation Y members. According to the results of a desk research conducted for the purposes of this paper, it can be concluded that members of generation $\mathrm{Y}$ expect from brands to adapt to their needs regarding promptness and reliability of information, adopt and implement personalized approach to communication, and allow them to participate in the process of value creation. As communication on social media is undergoing constant change, researchers should pay attention to the latest trends in this field. Namely, researchers' focus should be directed towards examining the influence of user-generated content, strategic role of video, potential of business podcasts as well as the role and significance of micro-bloggers in shaping contemporary marketing communication. 


\section{ACKNOWLEDGEMENT}

This paper is funded by Ministry of Education and Science of the Republic of Serbia.

\section{REFERENCES}

American Press Institute. (2015). How Millennials use and control social media. Accessed 15. 02. 2020. https://www.americanpressinstitute.org/publications/reports/survey-research/millennials-social-media/

Arnold, A. (2017). Three Major Reasons Why More Millennials Are Starting Blogs. Accessed 11.02.2020. https://www.forbes.com/sites/andrewarnold/2017/11/09/3-major-reasons-why-more-millennials-are-startingblogs/\#37cfef146ac6

Bolton, R. N., Parasuraman, A., Hoefnagels, A., Migchels, N., Kabadayi, S., Gruber, T., Loureiro, Y. K. \& Solnet, D. (2013). Understanding Generation $Y$ and their use of social media: A review and research agenda. Journal of Service Management, 24(3), 245-267. https://doi.org/10.1108/09564231311326987

Bruhn, M., Schoenmueller, V., \& Schäfer, D. B. (2012). Are social media replacing traditional media in terms of brand equity creation? Management Research Review, 35(9), 770-790. https://doi.org/10.1108/01409171211255948

Business Insider. (2018). Teens aren't using Facebook as much as millennials and Gen Xers - here's the social platform each generation uses the most. Accessed 10. 02. 2020. https://www.businessinsider.com/top-social-mediaplatform-by-age-group-2018-8

Chen, Y., Xie, J. (2008). Online Consumer Review: Word-of-Mouth as a New Element of Marketing Communication Mix. Management Science. 54(3). 477-491. DOI: 10.1287/mnsc.1070.0810.

Cheung, C. M. K., Lee, M. K. O., \& Rabjohn, N. (2008). The impact of electronic word-of-mouth: The adoption of online opinions in online customer communities. Internet Research, 18(3), 229-247. https://doi.org/10.1108/10662240810883290

Cheung, C. M. K., \& Thadani, D. R. (2012). The impact of electronic word-of-mouth communication: A literature analysis and integrative model. Decision Support Systems, 54(1), 461-470. https://doi.org/10.1016/j.dss.2012.06.008

Enginkaya, E., Yilmaz, H. (2014). What Drives Conumers to Interact with Brands through Social Media? A Motivation Scale Development Study. Procedia-Social and Behavioral Sciences. 148, 219-226. DOI:10.1016/j.sbspro.2014.07.037.

Gummerus, J., Liljander, V., Weman, E., \& Pihlström, M. (2012). Customer engagement in a Facebook brand community. Management Research Review. 35. https://doi.org/10.1108/01409171211256578

Hall, A. (2018). Most millennials only purchase items with online reviews, study finds. The Independent. Accessed 29. 1. 2020. https://www.independent.co.uk/news/business/millennial-online-review-products-research-internet-trustedrecommendations-a8245781.html

Hardey, M. (2011). Generation C - Content, creation, connections and choice. International Journal of Market Research. 53(6). 749-770. DOI: 10.2501/IJMR-53-6-749-770

Ibrahim, N. F., Wang, X., \& Bourne, H. (2017). Exploring the effect of user engagement in online brand communities: Evidence from Twitter. Computers in Human Behavior, 72, 321-338. https://doi.org/10.1016/j.chb.2017.03.005

Keller, K.L. (2009). Building strong brands in a modern marketing communications environment. Journal of Marketing Communications. 15(2-3). 139-155. DOI: 10.1080/13527260902757530.

Khan, H. U., Daud, A., Ishfaq, U., Amjad, T., Aljohani, N., Abbasi, R. A., \& Alowibdi, J. S. (2017). Modelling to identify influential bloggers in the blogosphere: A survey. Computers in Human Behavior, 68, 64-82. https://doi.org/10.1016/j.chb.2016.11.012

Khan, M. L. (2017). Social media engagement: What motivates user participation and consumption on YouTube? Computers in Human Behavior, 66, 236-247. https://doi.org/10.1016/j.chb.2016.09.024

Kilian, T., Hennigs, N., \& Langner, S. (2012). Do Millennials read books or blogs? Introducing a media usage typology of the internet generation. Journal of Consumer Marketing, 29(2), 114-124. https://doi.org/10.1108/07363761211206366

Killian, G., \& McManus, K. (2015). A marketing communications approach for the digital era: Managerial guidelines for social media integration. Business Horizons, 58(5), 539-549. https://doi.org/10.1016/j.bushor.2015.05.006

Mangold, W. G., \& Faulds, D. J. (2009). Social media: The new hybrid element of the promotion mix. Business Horizons, 52(4), 357-365.

McCorkindale, T., DiStaso, M.W., Fussell Sisco, H. (2013). How Millennials are Engaging and Building Relationships with Organizations on Facebook. The Journal of Social Media in Society. 2(1). 66-87. http://www.thejsms.org/tsmri/index.php/TSMRI/article/viewFile/15/18

Lamberton, C., Stephen, A.T. (2016). A Thematic Exploration of Digital, Social Media, and Mobile Marketing: 
Research Evolution from 2000 to 2015 and an Agenda for Future Inquiry. Journal of Marketing: AMA/MSI Special Issue. 80. 146-172. DOI: 10.1509/jm.15.0415.

Litvin, S., Goldsmith, R.E., Pan, B. (2008). Electronic Word-of-Mouth in Hospitality and Tourism Management. 29(3), 458-468. DOI: 10.1016/j.tourman.2007.05.011,

Marguerite Moore, (2012),"Interactive media usage among millennial consumers", Journal of

Consumer Marketing, 29(6). 436-444 DOI: 10.1108/07363761211259241

Pempek, T., Yermolayeva, Y.A., Calvert, S.L. (2009). College students' social networking experiences on Facebook. Journal of Applied Developmental Psychology. 30, 227-238. DOI: 10.1016/j.appdev.2008.12.010.

Smith, K. T. (2011). Digital marketing strategies that Millennials find appealing, motivating, or just annoying. Journal of Strategic Marketing, 19(6), 489-499. https://doi.org/10.1080/0965254X.2011.581383

Statista. (2019). Linkedln - Statistics \& Facts. Accessed 26. 1. 2020. https://www.statista.com/topics/951/linkedin/

Think with Google. (2018). Millennials YouTube Behavior Statistics. Accessed 23.01.2020. https://www.thinkwithgoogle.com/data/youtube-millennials-behavior-statistics/.

Tkalac Verčič, A., \& Verčič, D. (2013). Digital natives and social media. Public Relations Review, 39(5), 600-602. https://doi.org/10.1016/j.pubrev.2013.08.008

US Social Media Users by Generation. (2019). Emarketer. Accessed: 19.01.2020. https://www.emarketer.com/chart/226029/us-social-media-users-by-generation-2019-of-population.

Wang, X., Yu, C., \& Wei, Y. (2012). Social Media Peer Communication and Impacts on Purchase Intentions: A Consumer Socialization Framework. Journal of Interactive Marketing, 26(4), 198-208. https://doi.org/10.1016/j.intmar.2011.11.004

Ways to win customers at the Zero Moment of Truth - Google. Accessed: 21.01.2020. https://pbs.twimg.com/media/DImTRv-UQAAd_Be.jpg.

Wanhsiu, S.T., Linjuan, R.M. (2014). Consumer engagement with brands on social network sites: A cross-cultural comparison of China and the USA. Journal of Marketing Communications. 23(1), 2-21. DOI:10.1080/13527266.2014.942678.

Wind, J., \& Rangaswamy, A. (2001). Customerization: The next revolution in mass customization. Journal of Interactive Marketing, 15(1), 13-32. https://doi.org/10.1002/1520-6653(200124)15:1<13::AID-DIR1001>3.0.CO;2-\#

Wohn, D. Y., \& Bowe, B. J. (2016). Micro Agenda Setters: The Effect of Social Media on Young Adults' Exposure to and Attitude Toward News. Social Media and Society, 2(1). https://doi.org/10.1177/2056305115626750

Quick marketing. (2018). How Many Millennials Use Social Media. Accessed 28. 01. 2020. http://www.quickmarketing.com/many-millennials-use-social-media/

Lexico. Oxford dictionaries. Definition of Generation Y. Accessed 26. 01. 2020. https://en.oxforddictionaries.com/definition/generation_y 